\title{
Candidatos corruptos são punidos? Accountability na eleição brasileira de 2006
}

\begin{tabular}{c}
\hline \hline Mônica Mata Machado de Castro \\
Mestrado em Direito \\
Faculdades Milton Campos \\
Departamento de Ciência Política \\
Universidade Federal de Minas Gerais \\
Felipe Nunes \\
Doutorando em Ciência Política \\
Universidade da Califórnia - Los Angeles \\
\hline \hline
\end{tabular}

Resumo: Um dos principais temas da teoria democrática é o processo por meio do qual os cidadãos controlam a atividade de seus representantes. Neste artigo, analisam-se o sistema político brasileiro em termos gerais e as eleições de 1998 e 2006 em particular, com o objetivo de discutir se o processo de accountability vertical nos interstícios eleitorais torna os cidadãos capazes de punir ou recompensar seus representantes na eleição seguinte. A importância deste artigo está na análise dos efeitos do envolvimento de políticos nos escândalos do Mensalão e dos Sanguessugas, que abalaram a sociedade brasileira nos dois anos que precederam a eleição de 2006. Apesar dos custos de informação, dos baixos interesse e envolvimento político, da desigualdade social e pobreza característicos da sociedade brasileira, os eleitores foram capazes de punir grande parte dos políticos denunciados nos escândalos.

Palavras-chave: corrupção; accountability; reeleição

Abstract: One of the main themes in democratic theory is the process through which citizens control the activity of its representatives. In this paper we analyze the Brazilian political system in general terms and the 1998 and 2006 election in particular in order to argue that the processes of vertical accountability in the electoral gaps empower citizens in the sense of punishing and rewarding their representatives in the electoral moment. The importance of this work is guaranteed by the political context experienced by the country in the last couple of years before the 2006 election. A significant number of politicians had been involved in corruption scandals that resounded in the Brazilian society in a very negative way. Despite of the costs of information, limited time to be concerned with politics, and the huge social inequality allied to poverty, we show that voters have been able to punish those that had been involved in scandals.

Keywords: corruption; accountability; reelection

OPINIÃO PÚBLICA, Campinas, vol. 20, no 1, abril, 2014, p. 26-48 
CASTRO, M. M. M.; NUNES, F. Candidatos corruptos são punidos?...

\section{Introdução $^{1}$}

Um dos principais objetos de análise da Ciência Política é o grau em que os regimes democráticos contemporâneos se aproximam mais ou menos dos modelos de democracia que, entre outras características, supõem a participação informada e atenta dos cidadãos na escolha dos seus governantes (DAHL, 1989). Um país é considerado mais democrático se os representados tiverem condições de acompanhar e fiscalizar o trabalho de seus representantes, para avaliá-los e responsabilizá. los por suas ações ou omissões no governo e, assim, no processo eleitoral seguinte, reconduzi-los ou afastá-los do poder, recompensando os "bons" governantes, por meio de sua reeleição, e punindo os considerados "maus" políticos, com perda de seus mandatos (POWELL JR., 2000).

Sabe-se que esse processo de accountability vertical (O'DONELL, 1997; 2000), o controle dos eleitores sobre os eleitos, depende de uma série de fatores, entre os quais estão, de um lado, os arranjos institucionais vigentes, que favorecem ou dificultam a manifestação e expressão da vontade da maioria dos cidadãos na constituição dos governos e, de outro, a capacidade dos eleitores de se informar e acompanhar a atuação dos representantes para decidir o voto na eleição seguinte.

O objetivo deste artigo é discutir o processo de accountability vertical no Brasil por meio dos resultados da eleição nacional de 2006, para a Câmara dos Deputados. Esse pleito é especialmente propício para essa análise, porque foi precedido pela denúncia e investigação de escândalos de corrupção envolvendo, principalmente, parlamentares da Câmara dos Deputados: os chamados esquemas do Mensalão e dos Sanguessugas². É importante lembrar que, no caso do Mensalão especialmente, foram denunciados como participantes da "quadrilha" deputados da base do governo Luiz Inácio Lula da Silva, supostamente comandados por membros do primeiro escalão do Poder Executivo e da direção do Partido dos Trabalhadores (PT), justamente a agremiação que, desde sua criação, defendeu, como um de seus pilares, a bandeira da ética na política.

Nesse contexto, a pergunta que se pode fazer é: será que após cinco eleições consecutivas do atual período democrático brasileiro e da institucionalização de novos mecanismos de participação dos cidadãos nos interstícios eleitorais ${ }^{3}$, a população brasileira consegue controlar "melhor" ${ }^{4}$ seus representantes? Os eleitores puniram os candidatos à reeleição que estavam envolvidos nos escândalos? A familiaridade com a democracia, aliada à superexposição negativa desses parlamentares na mídia criaram condições desfavoráveis para a sua reeleição?

Considerando o sucesso do presidente Luiz Inácio Lula da Silva na disputa de 2006, analistas afirmaram que o eleitorado brasileiro não teria se preocupado com a questão da ética na política ao decidir como votar. As denúncias de corrupção, apesar de incluírem membros muito próximos do presidente, não impediram sua vitória. De alguma forma Lula conseguiu ficar protegido das denúncias e

\footnotetext{
1 Este artigo foi integralmente financiado pela Fundação de Amparo à Pesquisa de Minas Gerais (FAPEMIG), a quem agradecemos. Versão anterior do artigo, parcialmente financiado pela Diretoria de Assuntos Estudantis (DAE) da Universidade Federal de Minas Gerais, foi apresentada no 27th ILASSA Student Conference on Latin America, em fevereiro de 2007, na cidade de Austin, no Texas. Versão preliminar do texto também foi apresentada no encontro da IPSA de 2009, em Santiago, Chile. Agradecemos os comentários dos diversos debatedores nesses seminários. Os dados e códigos para replicar este estudo encontram-se em <http://thedata.harvard.edu/dvn/dv/felipenunes>.

2 Os dois escândalos, denunciados em 2005 e 2006, serão brevemente descritos à frente.

3 Importa lembrar, aqui, dos referendos, das comissões de participação popular no Legislativo, das audiências públicas, dos conselhos municipais e das experiências de orçamento participativo instituídos e implantados, no Brasil, após a promulgação da Constituição de 1988.

4 Ver a expressão "melhores interesses dos cidadãos", de Przeworski, Stokes e Manin (1999). Para os autores "melhor" significa que os representantes agem no interesse de, pelo menos, a maioria dos cidadãos.
} 
OPINIÃO PÚBLICA, Campinas, vol. 20, no 1, abril, 2014, p. 26-48

vencer a eleição de 2006, embora no segundo turno. Os ganhos resultantes das políticas sociais de seu governo teriam contado mais na decisão de voto da massa do eleitorado popular do que seu eventual envolvimento e responsabilidade nos esquemas de corrupção (RENNÓ, 2007; ZUcCo, 2008).

0 mesmo ocorreu no que se refere aos candidatos à Câmara dos Deputados? Os resultados eleitorais sugerem que a resposta é negativa (RenNó, 2007; PeReIRA, RenNó, SAmUels, 2011). Levando-se em conta que somente dois deputados foram impedidos de se apresentar como candidatos, porque seus mandatos foram cassados como resultado das Comissões Parlamentares de Inquérito, criadas em 2005 e 2006, e que, dos oitenta e oito deputados eleitos em $2002^{5}$, denunciados como participantes dos esquemas de corrupção, somente cinquenta foram apresentados nas listas partidárias à reeleição, é possível afirmar que, pelo menos do ponto de vista dos partidos e dos próprios políticos, estar envolvido nas denúncias funcionou como impedimento para sua apresentação como candidatos à reeleição para a Câmara dos Deputados, em 2006. Esse fato já indica que a expectativa dos próprios partidos e deputados era de que os eleitores os puniriam, não os reconduzindo ao cargo.

E em relação aos que concorreram à reeleição? É possível, com os resultados eleitorais, inferir algo a respeito da importância dada pelo eleitor ao problema da sua suposta participação nos esquemas de corrupção? Que fatores, provavelmente levados em conta pelo eleitorado para decidir em quem votar, aumentaram ou diminuíram as chances deles, na eleição de 2006?

Em comparação com outros fatores considerados nas análises sobre as condições para a reeleição dos representantes para as câmaras baixas, qual foi a importância das denúncias? Enfim, mantendo constantes outros fatores considerados na literatura especializada como condicionantes das chances dos deputados serem reeleitos, o envolvimento nos escândalos foi fator importante para explicar os resultados do pleito para a Câmara dos Deputados em 2006?

Neste artigo, analisam-se as seguintes questões: em primeiro lugar, discutem-se as limitações, decorrentes das regras eleitorais brasileiras, ao exercício do controle dos cidadãos sobre a atuação de seus representantes, por meio do voto. Segue-se a análise descritiva da distribuição dos deputados federais acusados de participação nos escândalos, incluídos nas listas partidárias à reeleição, classificados por partido político, e informa-se sobre os reeleitos e os derrotados na eleição de 2006, por tipo de denúncia. Na seção seguinte, discutem-se as principais variáveis consideradas na literatura especializada brasileira para explicar as chances de reeleição. Por fim, testam-se modelos explicativos da reeleição dos deputados federais, em 2006, incluindo algumas das variáveis levadas em conta na literatura e a denúncia de participação dos deputados nos escândalos do Mensalão e dos Sanguessugas.

\section{As Regras Eleitorais e o Controle dos Representantes}

O Brasil tem um sistema eleitoral que, de acordo com diagnósticos de diversos autores sobre os arranjos institucionais do país (NICOLAU, 2002; StRom, 2000; POWELl JR., 2000), não facilita o processo de accountability vertical, especialmente na escolha dos membros do Poder Legislativo. 0 país adota o sistema de representação proporcional de lista aberta: os partidos não definem sua ordem de preferência de candidatos, como ocorre na representação proporcional com lista fechada ou mista. 0

\footnotetext{
${ }^{5}$ Dados do jornal Folha de São Paulo on-line, de 14 de agosto de 2006.
} 
CASTRO, M. M. M.; NUNES, F. Candidatos corruptos são punidos?...

sistema eleitoral brasileiro tem consequências importantes na configuração das campanhas, de um lado, e nas alternativas dadas ao eleitorado, de outro. Como afirma Nicolau:

\begin{abstract}
"a literatura sobre os efeitos dos sistemas eleitorais chama a atenção para o fato de que a lista aberta estimula a predominância da reputação individual em detrimento da reputação partidária (CAREY e SHUGART, 1995). [Nessa situação], cada candidato organiza sua campanha (participação em eventos, confecção de material, arrecadação de fundos e prestação de contas dos gastos) de maneira praticamente independente dos diretórios partidários" (NICOLAU, 2002, p.223).
\end{abstract}

Importa chamar a atenção para o fato de que,

\begin{abstract}
"como o desempenho do partido deriva em larga escala do sucesso dos candidatos em obter votos, quando da organização das listas de candidatos, os partidos têm forte interesse de incluir indivíduos populares em seus ramos de atividade, mas não necessariamente com histórias de envolvimento em atividades partidárias (artistas, jogadores de futebol, radialistas, líderes religiosos, etc.)" (NICOLAU, 2002, p.223-224).
\end{abstract}

Como se sabe, o sistema eleitoral de representação proporcional com lista aberta incentiva, também, a manutenção do multipartidarismo que tem caracterizado o sistema político brasileiro nas últimas décadas. As regras vigentes permitem que cada partido apresente candidatos em número de até uma vez e meia das vagas em disputa nos distritos eleitorais. Dado o número de partidos políticos registrados no país, vinte e oito em 2006, a lista de candidatos, especialmente nos maiores distritos eleitorais - as unidades federadas brasileiras -, pode ser muito extensa. Embora o multipartidarismo favoreça a expressão de preferências em contextos heterogêneos (LIJPHART, 1999), a variedade de agremiações torna praticamente impossível para os eleitores obterem informação sobre todos os candidatos, avaliá-los e compará-los para fazer sua escolha6 ${ }^{6}$

As regras eleitorais brasileiras incluem, ainda, a possibilidade de coligações de partidos para a disputa das vagas, também, do Poder Legislativo. Esse arranjo incentiva a manutenção, no sistema partidário, de grande número de pequenos partidos, muitos sem consistência ideológica clara, mas que, se disputarem não coligados, não atingem o quociente eleitoral necessário para ocupar alguma das vagas. Além disso, essa regra permite que o voto conte para a vitória de candidato de partido diferente daquele escolhido pelo eleitor. Esse problema não é claramente identificado pelos cidadãos que, na verdade, podem ser levados a concluir, a partir do resultado da eleição, que seu voto foi desperdiçado, uma vez que a grande maioria dos candidatos não é eleita ${ }^{7}$.

A legislação brasileira permitia, até recentemente, a chamada migração partidária, sem maiores custos para os políticos ${ }^{8}$. Os deputados podiam trocar livremente de legenda logo depois de eleitos e durante seu mandato (MELO, 2000). Esse fenômeno atingiu todos os partidos (embora ocorresse

\footnotetext{
${ }^{6}$ O que se segue reproduz, em parte, Castro (2007).

7 A porcentagem média de votos dados aos candidatos não eleitos para Câmara dos Deputados no Brasil, de 1986 a 2006 , foi de 26,3\%, de acordo com os dados de Nicolau (2002), até 2002, e do Tribunal Superior Eleitoral, para 2006.

8 O Supremo Tribunal Federal (STF) decidiu, no dia 4 de outubro de 2008, que a infidelidade partidária pode gerar perda de mandato. A decisão passou a valer a partir do dia 27 de março de 2007, quando o Tribunal Superior Eleitoral (TSE) decidiu que o mandato político pertence ao partido, e não ao parlamentar. A discussão resultou de três mandados de segurança em que o Partido Popular Socialista (PPS), o Democratas (DEM) e o Partido da Social Democracia Brasileira (PSDB) pediam de volta os mandatos de deputados que abandonaram as legendas.
} 
com muito maior intensidade entre os de centro-direita do que entre os de esquerda) e afetou todos os níveis do sistema representativo (federal, estadual e municipal) ${ }^{9}$. Certamente a facilidade de migração partidária contribui para o enfraquecimento dos vínculos não só dos políticos, como também dos eleitores, com os partidos políticos.

Essas condições dificultam a formação e a manutenção de identidades partidárias estáveis que poderiam orientar as escolhas eleitorais. Nessa situação, não é de se estranhar o voto personalista, dado ao candidato popular, ou àquele indicado por chefes políticos locais, por conhecidos, amigos e colegas de trabalho, sem levar em conta, ou mesmo desconhecer, o partido ao qual o político pertence. Apesar de o eleitor ter a possibilidade de votar somente na legenda, manifestando sua preferência por um partido político, essa alternativa tem sido pouco utilizada no Brasil ${ }^{10}$.

Não é de se estranhar, também, que o eleitor não se lembre em quem votou, mesmo pouco tempo depois do pleito ${ }^{11}$. Mais ainda, não é de se estranhar que parte do eleitorado não se sinta, sempre, representada pelos deputados, tenha alto grau de desconfiança em relação aos partidos políticos ${ }^{12}$, não acompanhe seu desempenho na Câmara dos Deputados e não leve em conta essa questão ao decidir seu voto na eleição seguinte.

É importante enfatizar, ainda, duas características do processo político brasileiro que são, também provavelmente, efeitos das regras do sistema eleitoral: a baixa relação existente entre o aumento ou diminuição do número de votos dos candidatos aos cargos de representação proporcional e sua reeleição e o alto grau de renovação dos membros dos órgãos legislativos.

No Brasil, o sucesso de um candidato às eleições para a Câmara dos Deputados depende, entre outros fatores, da atuação do seu partido (que necessita ultrapassar o quociente eleitoral), do desempenho de outros partidos (caso haja coligação) e do número de votos que ele recebeu. A combinação de lista aberta com a possibilidade de os partidos coligarem-se reduz a previsibilidade dos resultados eleitorais: partidos coligados podem eleger candidatos mesmo sem atingir o quociente eleitoral, candidatos podem aumentar sua votação e não se reeleger, enquanto outros podem obter um número de votos menor do que na eleição anterior e, ainda assim, garantir sua reeleição.

A análise da primeira questão é relevante porque uma forma de dimensionar a capacidade de controle dos eleitores sobre seus representantes é comparar o contingente de votos em duas eleições sucessivas. Conforme sugeriu Nicolau (2002), o aumento de votos de um parlamentar indicaria o reconhecimento, por parte do eleitor, do bom trabalho desenvolvido durante o mandato, enquanto a diminuição evidenciaria que parte dos eleitores anteriores abandonou o parlamentar. A Tabela 1 permite observar o sucesso e o fracasso das tentativas de reeleição parlamentar no Brasil. Nela, os deputados

\footnotetext{
9 Uma análise das mudanças ocorridas na Câmara dos Deputados revela a intensidade do fenômeno. O número de deputados que abandonaram o partido pelo qual foram eleitos, entre 1983 e 2003 é impressionante: dos 2.972 representantes eleitos, 852 $(28,7 \%)$ trocaram de partido ao longo da legislatura, alguns deles mais de uma vez. Os dois maiores partidos brasileiros, o PMDB e o PFL, por exemplo, perderam, respectivamente, 22,7\% e 23\% dos deputados eleitos no período (MELO, 2004).

10 A média dos votos em legenda para a Câmara dos Deputados, entre 1986 e 2006, foi de 8,9\%.

11 Pesquisa realizada pelo ESEB (2002) junto aos eleitores brasileiros, a respeito das eleições de 2002, revela que a memória do eleitor no que se refere ao voto dado no pleito anterior ainda é reduzida. Perguntados sobre em quem votaram para o cargo de deputado federal, os entrevistados deram as seguintes respostas: $45,3 \%$ conseguiram se lembrar do Deputado Federal em que votaram, mas $41,9 \%$ não se lembraram, nulos e brancos somaram 9,5\%, 1,8\% afirmou ter votado na legenda e $1,5 \%$ que não votou.

12 Pesquisa realizada pelo Latinobarômetro junto a cidadãos brasileiros mostrou, em 2006, que apenas $20 \%$ confiavam nos partidos políticos e $22 \%$ no congresso. Essas foram as duas instituições menos confiáveis na opinião dos brasileiros em comparação com igreja, polícia, rádio, televisão, forças armadas, governo, dentre outras
} 
CASTRO, M. M. M.; NUNES, F. Candidatos corruptos são punidos?...

federais eleitos em 1994 e em 2002, que tentaram a reeleição em 1998 e 2006, respectivamente, foram divididos de acordo com o aumento ou a diminuição do percentual de votos obtido sobre o total de votos válidos no estado e o sucesso do deputado em ser reeleito ${ }^{13}$.

Tabela 1

Aumento ou diminuição da votação dos deputados que se recandidataram Brasil 1998 e 2006 (\%)

\begin{tabular}{|l|c|c|c|c|}
\hline \multirow{2}{*}{} & \multicolumn{2}{|c|}{ Votação 1994-1998 } & \multicolumn{2}{c|}{ Votação 2002-2006 } \\
\cline { 2 - 5 } & Aumentou & Diminuiu & Aumentou & Diminuiu \\
\hline Reeleito & 94,9 & 52,9 & 88,2 & 47,0 \\
\hline Não-reeleito & 5,1 & 47,1 & 11,8 & 53,0 \\
\hline Total & $\begin{array}{c}100 \\
(157)\end{array}$ & $\begin{array}{c}100 \\
(227)\end{array}$ & $\begin{array}{c}100 \\
(170)\end{array}$ & $\begin{array}{c}100 \\
(215)\end{array}$ \\
\hline
\end{tabular}

Fonte: Nicolau (2002) e Tribunal Superior Eleitoral (TSE).

Pode-se observar que, nas duas eleições, o aumento do número de votos de um candidato não garante sua reeleição e, mais importante, candidatos podem ter menos votos que antes e, mesmo assim, serem reeleitos. Note-se que mais da metade dos deputados (53\%) que obtiveram votação menor em 1998, em relação a 1994, conseguiram uma cadeira na Câmara dos Deputados. Entretanto, há alguma diferença entre as duas eleições: em 2006, aumenta a proporção de deputados que, mesmo tendo mais votos, perderam o mandato e diminui a proporção de candidatos reeleitos embora com menos votos do que na eleição anterior. Note-se que a comparação desses resultados, das eleições de 1998 e de 2006 para a Câmara dos Deputados, já sugere que as denúncias de corrupção impactaram o Legislativo.

Tabela 2

Taxa de renovação bruta e líquida Câmara dos Deputados Brasil 1986/2006 (\%)

\begin{tabular}{|c|c|c|c|c|c|c|}
\hline & DESISTIU & REELEITO & DERROTADO & TOTAL & RENOVB ${ }^{14}$ & RENOVL $^{15}$ \\
\hline $1986-1990$ & 158 & 177 & 152 & 487 & 63,7 & 46,2 \\
\hline $1990-1994$ & 155 & 216 & 132 & 503 & 57,1 & 37,9 \\
\hline $1994-1998$ & 155 & 216 & 132 & 503 & 57,1 & 37,9 \\
\hline $1998-2002$ & 131 & 257 & 125 & 513 & 49,9 & 32,7 \\
\hline $2002-2006$ & 121 & 259 & 133 & 513 & 49,5 & 33,9 \\
\hline
\end{tabular}

$\mathrm{Na}$ Tabela 2, pode-se observar a segunda característica identificada anteriormente, sobre o grau de renovação dos membros da Câmara dos Deputados. Ele parece alto. A renovação bruta média . que leva em conta os deputados que desistiram de se apresentar como candidatos - foi de $55,5 \%$ para todo o período de 1986 a 2006; a renovação líquida - que considera somente os deputados que

\footnotetext{
13 Interessa comparar os resultados desses dois anos porque foram eleições em que o principal candidato à Presidência da República disputava a reeleição: Fernando Henrique Cardoso, em 1998, e Lula, em 2006; esse fator é, assim, controlado.

14 RENOVB (Renovação Bruta) $=($ DESIST + DERROT) $/($ TOT $) \times 100$

15 RENOVL (Renovação Líquida) $=($ DERROT $) /($ REEL + DERROT) $\times 100$
} 
OPINIÃO PÚBLICA, Campinas, vol. 20, no 1, abril, 2014, p. 26-48

disputaram a reeleição - foi em média de $37,7 \%{ }^{16}$. Note-se, entretanto, a diminuição dos números no tempo, tendência que, de acordo com os dados, não se mantém em 2006.

Mais uma vez se coloca a pergunta: os eleitores utilizaram a eleição como uma forma de punir os parlamentares envolvidos nas denúncias de corrupção de 2005 e $2006 ?$

A Tabela 3 apresenta as médias, por região demográfica do país, de deputados federais reeleitos e derrotados, entre os que concorreram à reeleição em 1998 e em 2006. Observa-se, em todas as regiões, que o percentual de candidatos reeleitos é menor em 2006 se comparado a 1998. E as diferenças percentuais são grandes: a média de sucesso eleitoral desse grupo, em 1998, foi de 69,7\% e, em 2006, caiu para 58,8\%. Tais dados sugerem, também, que os cidadãos puniram a Câmara dos Deputados marcada, naquela legislatura, pelos escândalos do Mensalão e pelos Sanguessugas.

Tabela 3

Deputados Federais que Concorreram à Reeleição

Brasil 1998 e 2006 (\%)

\begin{tabular}{|c|c|c|c|c|}
\hline & \multicolumn{2}{|c|}{1998} & \multicolumn{2}{c|}{2006} \\
\hline Região & reeleitos (média) & $\begin{array}{c}\text { não-reeleitos } \\
\text { (média) }\end{array}$ & reeleitos (média) & não-reeleitos (média) \\
\hline Norte & 65,4 & 34,6 & 50,1 & 49,9 \\
\hline Nordeste & 76,9 & 23,1 & 65,9 & 34,1 \\
\hline Sudeste & 66,2 & 33,8 & 50,8 & 49,2 \\
\hline Sul & 70,9 & 29,1 & 65,6 & 34,4 \\
\hline Centro-Oeste & 65,4 & 34,6 & 61,7 & 38,3 \\
\hline Brasil & 69,7 & 30,3 & 58,8 & 41,1 \\
\hline
\end{tabular}

Fonte: Nicolau (2002) e Tribunal Superior Eleitoral (TSE).

Apesar de todas as dificuldades, os eleitores parecem ter conseguido dar um recado ao sistema político e aos governantes na eleição nacional brasileira de 2006.

\section{Os Escândalos e o Desempenho dos Candidatos Acusados}

Nos dois últimos anos do seu primeiro mandato (2003-2006), o governo Lula passou por crises políticas graves. A primeira, em 2005, se deu a partir da denúncia de que parlamentares da base aliada recebiam dinheiro de "caixa dois" 17 para votar em projetos de interesse do Executivo, escândalo que ficou conhecido como Mensalão. A segunda, em 2006, a denúncia de compra de ambulâncias superfaturadas com recursos de emendas parlamentares, foi deflagrada a partir de investigação realizada pela Polícia Federal (PF) e ficou conhecida como o esquema dos Sanguessugas. Esse foi um dos períodos de crise política de maior repercussão internacional após a redemocratização do país.

O estopim da crise do Mensalão foi a revelação de uma fita de vídeo que mostra o exfuncionário dos Correios, Maurício Marinho, negociando propina com empresários interessados em participar de licitação na agência. No vídeo, o funcionário dizia ter o respaldo do deputado federal Roberto Jefferson, do Partido Trabalhista Brasileiro (PTB). Em resposta à acusação, o deputado Roberto

\footnotetext{
16 Não foi possível encontrar dados de outros países de forma a poder avaliar, comparativamente, as taxas de renovação dos parlamentos.

17 Refere-se aqui aos recursos para financiamento de campanhas eleitorais que não são declarados nem pelo doador nem pelo beneficiário do recurso.
} 
CASTRO, M. M. M.; NUNES, F. Candidatos corruptos são punidos?...

Jefferson concedeu entrevista ao jornal Folha de São Paulo, publicada no dia 6 de junho de 2005, onde afirmou que o Ministro Chefe da Casa Civil, deputado José Dirceu (PT), seria o responsável por esquema que envolvia todos os partidos da base aliada: por meio do superfaturamento, especialmente de contas de publicidade do governo federal e de estatais controladas por aliados políticos, os chamados "operadores do Mensalão" repassavam recursos públicos para partidos políticos supostamente cobrirem os gastos de seus candidatos nas campanhas eleitorais. O equacionamento das dívidas seria retribuído com apoio dos partidos aos projetos enviados pelo governo ao Congresso.

Em 14 de junho, foi criada a Comissão Parlamentar Mista de Inquérito (CPMI) dos Correios - do Senado Federal e da Câmara dos Deputados - presidida pelo Senador Delcidio Amaral (PT) e com a relatoria ocupada pelo deputado Osmar Serraglio, do Partido do Movimento Democrático Brasileiro (PMDB). Os titulares da comissão defenderam a ampliação do foco das investigações para além dos Correios, com a tese de que o dinheiro de corrupção nas estatais seria a fonte dos recursos do chamado Mensalão. A CPMI dos Correios logo se transformou no principal palco de investigações do suposto esquema. Focou suas investigações, também, nos possíveis fornecedores de recursos para os pagamentos.

A Comissão Parlamentar Mista de Inquérito finalizou seus trabalhos sem aprovar um relatório final, embora tenha aprofundado as investigações sobre a questão e contribuído para cassação dos mandatos dos deputados Roberto Jefferson e José Dirceu. Foi o Ministério Público (MP), por meio do procurador-geral da República, Antonio Fernando de Souza, que apresentou denúncia ao Supremo Tribunal Federal (STF) contra quarenta pessoas envolvidas no esquema ${ }^{18}$. A lista incluiu ex-ministros, políticos, funcionários públicos, empresários e publicitários. Dos 40 acusados, 19 eram parlamentares. Foram citados no processo os deputados João Paulo Cunha (PT-SP), José Janene (PP.PR), Romeu Queiroz (PTB-MG), João Magno (PT-MG), Professor Luizinho (PT-SP) e Pedro Henry (PP-MT). Faziam parte, ainda, da lista do procurador os ex-deputados que foram cassados - Roberto Jefferson e José Dirceu - e os que renunciaram ao mandato para escapar do processo de cassação por terem recebido recursos do Mensalão: José Borba, Paulo Rocha, Pedro Correa, Valdemar Costa Neto e Carlos Rodrigues. A denúncia deu entrada no plenário do STF, em agosto de 2007, tendo sido relatada pelo ministro Joaquim Barbosa. Vinte dias após a leitura do relatório, o Supremo aceitou as denúncias contra os 40 acusados, transformando-os em réus do processo. O julgamento ocorreu no segundo semestre de 2012, com grande repercussão na imprensa. Atualmente, início de 2013, o STF está finalizando o relatório final do julgamento.

Em 2006, outra denúncia abalou, também, o governo: o chamado escândalo dos Sanguessugas. Os envolvidos foram chamados de "máfia das ambulâncias", porque fraudavam a venda de ambulâncias para prefeituras de diversos estados do país. Segundo o jornal Folha de São Paulo de 10 de outubro de 2006, o esquema começava com o contato com prefeitos interessados. Apresentava-se a eles a possibilidade de receber uma ambulância completa antes de serem cumpridos todos os trâmites legais. Com a concordância do prefeito, a "quadrilha" acionava assessores de parlamentares, que preparavam emendas a serem apresentadas por deputados e senadores. 0 texto era aprovado no Congresso Nacional e, a seguir, no Ministério da Saúde, funcionários teriam a incumbência de apressar a aprovação dos

${ }^{18}$ Como o processo incluía deputados federais, de acordo com a legislação brasileira, ele foi enviado diretamente para o STF. 
OPINIÃO PÚBLICA, Campinas, vol. 20, no 1, abril, 2014, p. 26-48

convênios e facilitar a liberação dos recursos. Os veículos eram entregues em tempo recorde, superfaturados e sem os equipamentos necessários para atendimentos de emergência. No total, a quadrilha teria movimentado $\mathrm{R} \$ 110$ milhões desde 2001 e entregue 1.000 veículos às prefeituras.

A denúncia, que permitiu o início das investigações, partiu do próprio governo: a Controladoria Geral da União alertou a Polícia Federal (PF) sobre as irregularidades. Essa iniciou as investigações em 2004 e, com o auxílio da Receita Federal, identificou empresas fantasmas montadas para dar aparência de veracidade às concorrências de venda das ambulâncias. Foram quebrados, com a autorização da Justiça, os sigilos bancário e telefônico de sessenta pessoas. A primeira denúncia do Ministério Público envolveu cento e quarenta pessoas, incluindo deputados e senadores. No final, e ainda sob investigação, cinquenta e nove foram citadas no processo, entre as quais quarenta eram deputados federais. 0 processo ainda tramita em diversas instâncias da justiça brasileira. Em onze dos vinte e sete estados há processos envolvendo parlamentares, prefeitos e empresários. Só em São Paulo, o Ministério Público Federal já propôs ações sobre desdobramentos da Operação Sanguessuga em Sorocaba, Jaú, Piracicaba, e Presidente Prudente. Até o momento, o ex-prefeito de Nova Guarita, norte de Mato Grosso, a ex. assessora do Ministério da Saúde, e dois empresários já foram punidos por improbidade administrativa.

Esses escândalos repercutiram na eleição nacional para a Câmara dos Deputados ocorrida em outubro de 2006. Como foi informado anteriormente, entre os acusados de envolvimento, cinquenta se candidataram à reeleição para o cargo de deputado federal naquele ano. A Tabela 4 mostra esses deputados distribuídos por partidos políticos. Considerando somente o Mensalão, a maioria deles é do PT (6 em 9). Mas, se levamos em conta os dois escândalos, os candidatos são, em número maior, do Partido Liberal (PL), do PTB e do PP. Esses três partidos têm em comum duas características: todos participaram da base aliada do primeiro governo Lula, mesmo ocupando campo ideológico distante do partido do Presidente - à direita.

Tabela 4

Candidatos à reeleição para deputado federal, em 2006, envolvidos nos escândalos, por partido

\begin{tabular}{|l|c|c|c|c|c|}
\hline \multirow{2}{*}{} & \multicolumn{2}{|c|}{ Deputados acusados nos escândalos } & \multirow{2}{*}{ Total } & \multirow{2}{*}{ Reeleitos } \\
\cline { 2 - 5 } & Mensalão & Sanguessuga & $\begin{array}{c}\text { Mensalão e } \\
\text { Sanguessuga }\end{array}$ & \\
\hline PP & 1 & 7 & 1 & 9 & 2 \\
\hline PT & 6 & 1 & 0 & 12 & 0 \\
\hline PTB & 1 & 11 & 0 & 5 & 1 \\
\hline PMDB & 0 & 5 & 0 & 10 & 0 \\
\hline PSC & 0 & 1 & 0 & 3 & 0 \\
\hline PL & 0 & 9 & 0 & 3 & 1 \\
\hline PFL & 0 & 3 & 0 & 50 & 9 \\
\hline PSB & 9 & 40 & 1 & & 1 \\
\hline TOTAL & 1 & & 0 & \\
\hline
\end{tabular}

Fonte: Banco de Dados das eleições de 2006. 
CASTRO, M. M. M.; NUNES, F. Candidatos corruptos são punidos?...

Entre os 50 candidatos acusados nos dois esquemas de corrupção, que decidiram se recandidatar, apenas 9 foram reeleitos; a grande maioria, $82 \%$ dos envolvidos nos escândalos, não foi reconduzida pelos cidadãos à Câmara dos Deputados, através do voto. 0 partido com maior número de candidatos bem-sucedidos foi o PT (3 eleitos entre os 7 que se recandidataram). Em contraposição, o PL e o PTB foram os maiores prejudicados: o primeiro elegeu 2 dos 10 que se recandidataram e o segundo não elegeu nenhum dos 12 candidatos.

Esse resultado mostra que, superando todas as dificuldades impostas pelo sistema eleitoral, a maioria dos parlamentares envolvidos em escândalos, que concorreram à reeleição, foi punida pelos cidadãos brasileiros, simplesmente por meio do voto.

Considerando o sucesso eleitoral por tipo do escândalo (Tabela 5), os mais bem-sucedidos na reeleição foram os acusados de receber Mensalão: 5 dos 9 candidatos foram vitoriosos. Entre os deputados envolvidos na chamada Máfia das Ambulâncias, apenas 3 dos 40 candidatos conseguiram reeleger-se. 0 deputado que esteve envolvido nos dois escândalos também se reelegeu.

Tabela 5

Deputados acusados, reeleitos em 2006, por tipo de escândalo

\begin{tabular}{|c|c|c|}
\hline Escândalo & Candidatos & Reeleitos \\
\hline Mensalão & 9 & 5 \\
\hline Sanguessuga & 40 & 1 \\
\hline Mensalão e Sanguessuga & 1 & 9 \\
\hline Total & 50 & 3 \\
\hline
\end{tabular}

Duas considerações são importantes a partir desses resultados. Em primeiro lugar, é preciso lembrar que o Mensalão foi denunciado em 2005, mais de um ano antes do processo eleitoral de 2006. O fator tempo em relação ao evento pode ter impactado o comportamento dos eleitores ${ }^{19}$. Os dados indicam que os deputados envolvidos no escândalo que explodiu a poucos meses da eleição foram mais severamente punidos pelos eleitores. Em segundo lugar, como se mostrou antes, a maioria dos candidatos envolvidos no Mensalão era do PT, partido do presidente Lula, que conseguiu ficar imune às denúncias e se reeleger, provavelmente contribuindo, de alguma forma, para a vitória dos deputados de seu partido.

\section{Determinantes da Reeleição dos Representantes}

Os principais estudos sobre eleições legislativas no Brasil tratam, especialmente, dos efeitos de três dimensões sobre os resultados eleitorais: (1) do arranjo institucional brasileiro (NICOLAU, 1996; TAVARES, 1998; LAMOUNIER, 1989), (2) do comportamento parlamentar (SANTOS, 1999; FIGUEIREDO e LIMONGI, 1999; Pereira, 2000) e (3) do comportamento eleitoral (BAQUeRo, 1997; RenNó, 2000).

Esses estudos contribuíram para a compreensão do funcionamento do sistema político brasileiro e permitiram a identificação das estratégias dos políticos para manter suas carreiras políticas.

\footnotetext{
19 Hipótese que será testada nas próximas seções.
} 
Mas poucas são as tentativas de testar um modelo teórico para explicar a reeleição dos deputados federais. A principal referência continua sendo a dos estudos voltados para a realidade norte-americana, nas mais diversas abordagens (Jacobson, 1990; Krasno, Green, Cowden, 1994; Kazee e ThornberRy, 1990; Cox, MCCuBbins, 2005; CAMPBELL, 1997; dentre outros). Considerando que modelos explicativos com a variável dependente "reeleição" são escassos na literatura especializada sobre o Brasil, é preciso ressaltar algumas tentativas nessa direção.

O trabalho de Ames (2001) ${ }^{20}$ buscou relacionar os resultados eleitorais com a atuação dos parlamentares, analisando a eleição para a Câmara dos Deputados, em 1998. Segundo o autor, a base eleitoral espacial dos parlamentares tem impacto direto sobre o tipo de estratégia que ele empreende no interior do Legislativo. Após mapear a dispersão e configuração do eleitorado de legisladores com perfis diferentes, Ames conclui que a maioria deles representaria interesses concentrados espacialmente. Sendo assim, as chances de reeleição do deputado aumentariam com sua capacidade de difundir a impressão de que "lutou" pelos municípios que "representa" na Câmara dos Deputados. Essa luta estaria representada pelo sucesso em transferir recursos federais para esses municípios. Nessa perspectiva, a associação entre estratégias de credit claiming e pork barrel, discutidas originalmente por Mayhew (1974), explicariam o sucesso eleitoral dos legisladores no Brasil.

Pereira e Rennó $(2001 ;$ 2007) foram os responsáveis pelos maiores avanços no preenchimento das lacunas deixadas por Ames. Segundo os autores,

\footnotetext{
"o sistema político brasileiro cria incentivos para que os eleitores se preocupem mais com os benefícios locais do que com a performance nacional dos seus representantes, o que faz com que a participação dos parlamentares, no âmbito nacional, seja orientada pela busca de benefícios que possam ser utilizados no plano local, como forma de alcançar maiores retornos eleitorais" (PEREIRA; RENnó, 2001, p. 1).
}

Para sustentar esse argumento os autores se debruçaram sobre um enorme conjunto de variáveis para explicar "o que o reeleito tem". É possível distinguir entre dois conjuntos básicos de variáveis utilizados nos seus trabalhos: aspectos políticos locais - relativos à atuação dos parlamentares em suas respectivas bases eleitorais - e fatores políticos nacionais - ligados à atuação dos legisladores no Congresso e à influência do Presidente da República e dos partidos políticos na eleição para o Legislativo. Com referência à primeira dimensão, os autores investigaram os efeitos da distribuição de votos do candidato, do grau de dominação e competição no principal reduto eleitoral, dos gastos de campanha, das características do município, da influência de pork barre/ e credit claiming e dos padrões de coalizão com os atores políticos regionais e locais. Em relação à segunda dimensão, utilizam as variáveis: participação do deputado na arena legislativa, sua posição na hierarquia da Câmara e do partido, filiação partidária e papel do presidente nas eleições legislativas. Seus resultados mostram que as duas dimensões exercem influência nas chances de reeleição. Contudo, a distribuição de recursos locais proporciona muito mais retorno eleitoral do que as atividades legislativas na Câmara ou as posições assumidas em relação a determinadas matérias.

\footnotetext{
${ }^{20}$ Ver resenha de Melo (2005) publicada na Revista de Sociologia e Política.
} 
CASTRO, M. M. M.; NUNES, F. Candidatos corruptos são punidos?...

Em trabalho posterior, os autores mostraram que uma variável relevante para explicar o sucesso eleitoral de deputados federais no Brasil é o presidente estar concorrendo à reeleição. Pereira e Rennó (2007) chegaram a tal conclusão comparando os efeitos das variáveis explicitadas anteriormente para as eleições de 1998 e 2002. Conforme mostram, a proximidade do deputado com o Executivo, bem como as transferências de benefícios e as políticas locais controladas pelo presidente foram decisivas para o sucesso dos deputados que buscavam a reeleição em 1998. Já em 2002, quando não havia um candidato concorrendo à reeleição para presidente, o efeito do Executivo nas eleições legislativas quase desaparece.

Samuels (2000; 2002), por outro lado, afirma que são o apoio dos governadores e os recursos utilizados nas campanhas eleitorais que realmente importam na distribuição das vagas para a Câmara dos Deputados. Os governadores gerariam ganhos eleitorais para os deputados ao aparecerem com eles em um bloco eleitoral que inclui, também, candidatos ao Senado. O apoio do governador à época da eleição não poderia ser desprezado como instrumento de pork bastante eficiente, uma vez que os seus poderes discricionários para alocação dos recursos na constituency do candidato seriam tão efetivos quanto os recursos que esse candidato pode carregar do governo federal, porém mais simples de se conseguir. Os dados do autor sustentam que o apoio do governador influencia positivamente as chances de eleição do legislador. De outro lado, o trabalho de busca de pork no legislativo nacional é recompensado com dinheiro para financiar a campanha eleitoral. Os resultados de Samuels mostram que o retorno do pork não é auferido em votos diretamente, mas pela transferência de recursos privados dos beneficiados pelas emendas, para o financiamento das campanhas eleitorais.

É importante lembrar que as variáveis consideradas por esses autores como determinantes do sucesso eleitoral dos parlamentares estão justificadas em teorias formuladas para o caso norte. americano. Conforme afirmamos antes, foi Mayhew (1974) quem propôs a conexão causal entre "transferências de recursos para bases eleitorais" e reeleição, pensando no cenário em que os deputados federais são eleitos em distritos uninominais, como nos Estados Unidos. Para testar essa teoria no Brasil seria preciso mapear os votos dos parlamentares e propor uma classificação dos tipos de bases eleitorais possíveis, como fez Ames (2001).

Cireno e Lubambo (no prelo) mostram que o índice de concentração eleitoral municipal ${ }^{21}$, que compõe o indicador de dominância de Ames (2001), é fator crucial para entender o sucesso eleitoral dos parlamentares. Segundo os autores, os apoios locais têm a maior influência nas chances de eleição e no número de votos dos candidatos, mesmo comparando candidatos competitivos e não-competitivos ${ }^{22}$. Os resultados de sua análise mostram que o efeito desse fator é grande, mesmo com o controle do apoio do presidente, explorado por Pereira e Rennó (2007), e do governador, trabalhado por Samuels (2000).

Há, ainda, pesquisas em que se estuda o impacto das características pessoais do parlamentar sobre seu sucesso nas eleições. Traços como sexo, idade e escolaridade são considerados para verificar se há diferenças significativas entre as probabilidades de eleição de candidatos de diferentes grupos sociais. Conforme argumenta Schwindt-Bayer (2009), a implementação de cotas para as mulheres nas

\footnotetext{
21 O índice é o produto da proporção dos votos de um candidato, em um município, ponderado pelo peso dessa votação no total de seus votos. Para diminuir o efeito da distorção que as grandes cidades gerariam neste índice, a unidade utilizada, nesses casos, foi a zona eleitoral, e não o município (CIRENo e LUBAMBO, no prelo).

22 Foram considerados competitivos os candidatos que conseguiram, no mínimo, metade dos votos necessários para o preenchimento da última cadeira em cada estado, independente de coligação (CIRENo e LUBAMBO, no prelo).
} 
eleições de 26 países ao redor do mundo mostra como esse grupo é desprivilegiado na disputa por votos com os homens. Pesquisas que tratam da senioridade dos parlamentares (SANTOS, 2000) mostram que parlamentares em busca da reeleição têm menos chance de sucesso se comparados aos candidatos novatos. No caso da escolaridade, as pesquisas têm mostrado que a grande maioria dos deputados federais possui alto grau de instrução, mesmo em países subdesenvolvidos (SAEZ e LOPES, 2007). Assim, o efeito dessa variável é próximo de zero para diversos legislativos ao redor do mundo.

As análises sobre sucesso eleitoral consideram, sempre, o papel dos partidos nas arenas eleitoral e partidária. Os partidos auxiliariam ou, pelo menos, deveriam auxiliar os eleitores na identificação das propostas do candidato, quando não há informação sobre sua trajetória e sua posição política (ERIKSON, 1988). Com a atuação no interior do Legislativo, os partidos deveriam ser capazes de mostrar ao eleitor o posicionamento dos seus candidatos frente ao governo e à oposição. Afinal, se a política se refere à decisão sobre a melhor alocação de recursos públicos, então, avaliar se o governo vai bem ou mal e se o deputado se beneficia ou não de fazer parte do governo ou da oposição deve ter efeito considerável (Pereira; Rennó, 2007; Cox; Magar, 1999).

Considera-se, ainda, o papel do número de votos dos parlamentares que buscam reeleição, quando se procura explicar a punição ou a recompensa dos parlamentares pelos eleitores. Como já colocado, os efeitos desse fator são controversos: de acordo com Nicolau (2002), a possibilidade de que um eleitor acompanhe seu representante é pequena, sobretudo porque o número de eleitores que consegue eleger os deputados nos quais votou é baixo e porque grande parte dos eleitores não se lembra do voto anterior para a Câmara dos Deputados. E os resultados de Nicolau (2002) mostram que a diminuição do número de votos, em 2002, não significou, sempre, a perda do mandato dos parlamentares.

Finalmente, parece importante considerar a hipótese fundada na perspectiva sociológica, que parte do suposto de que características da estrutura socioeconômica de estados e regiões podem ser tomadas como fatores contextuais que, de modo geral, condicionam a influência de outras variáveis sobre o comportamento político dos eleitores. Assim, o sucesso eleitoral dos deputados seria, também, influenciado pelas características socioeconômicas dos estados e regiões brasileiros, que, como se sabe, variam muito. É importante lembrar que a política brasileira ainda convive com cenários de clientelismo, identificados desde o começo da República (ANDRADE, 2007; LEAL, 1975) e que condições precárias de vida provavelmente ampliam as chances de manutenção dos chamados "coronéis" no Legislativo: políticos que, utilizando a máquina do estado, promovem suas candidaturas por meio da troca de favores com suas clientelas e, muitas vezes, ainda procuram 'comprar' os votos dos eleitores.

\section{Teste do Modelo Explicativo}

Como foi apresentado no início, o objetivo específico deste artigo é verificar se as denúncias de participação dos candidatos em algum dos esquemas de corrupção ocorridas em 2005 e 2006 - fator que pode ser considerado um aspecto da sua atuação parlamentar - tiveram algum impacto no resultado eleitoral de 2006. Contudo, levando-se em conta as principais pesquisas referidas, serão incluídos na análise, como variáveis de controle, outros fatores considerados na literatura especializada.

A principal variável independente, tratada como dummy, é ter sido acusado de participação em algum dos escândalos. Ser acusado no Mensalão ou no Sanguessugas é definido como (1) e não ser é 
CASTRO, M. M. M.; NUNES, F. Candidatos corruptos são punidos?...

(0). A hipótese é que esse fator diminui as chances dos candidatos serem reeleitos. Consideraram-se, também, os efeitos de cada um dos escândalos separadamente.

Como controle foram incluídas no modelo as seguintes variáveis:

a) alguns dos fatores considerados na literatura sobre reeleição no Legislativo brasileiro, tais como: o partido do candidato classificado na escala de direita $\mathrm{x}$ esquerda (esquerda e centro, em contraposição à direita) ${ }^{23}$; a diferença de votos recebidos na eleição de 2006 em relação a 2002, definida, também como dummy. aumentou (1) ou diminuiu (0); o acesso a benefícios particularistas para as respectivas bases eleitorais, medido por meio da taxa de sucesso do legislador em prover emendas orçamentárias para sua base nos últimos dois anos de governo (2005/2006): o efeito pork (PeREIRA; RenNó, 2004) ${ }^{24}$.

b) duas variáveis que se referem às consequências das leis eleitorais brasileiras nas condições da disputa por vagas nos legislativos, fatores esses não levados em conta nas análises anteriores sobre reeleição: se o deputado migrou de partido na legislatura anterior e um indicador do grau de competição política nas unidades federadas, em 2006, a proporção de candidatos por vaga para a disputa por cargo de deputado federal. Com relação ao primeiro fator, considera-se, seguindo a análise de Melo (2000), que a mudança de partido pode ter sido uma das estratégias utilizadas pelos candidatos para, segundo sua própria avaliação, aumentar as chances de reeleição. Por outro lado, quanto maior o número de candidatos por vaga nas unidades federadas, por efeito simplesmente matemático, maiores as dificuldades para cada um ser eleito ou reeleito;

c) atributos dos candidatos: sexo (masculino (1), feminino (0)), idade (variável contínua que varia de 20 a 90 anos) e grau de escolaridade (que varia de (0), "lê e escreve", até (6), "tem curso superior completo");

d) um indicador da variedade das condições socioeconômicas dos estados da federação: a desigualdade da distribuição de renda, medida pelo percentual de pobres, para cada uma das unidades federadas, em $2006^{25}$. Esse indicador foi incluído considerando-se a perspectiva sociológica indicada. A hipótese subjacente é que essa variável está associada ao sucesso eleitoral de deputados federais, já que a pobreza tende a produzir eleitores mais dependentes de subsídios particularistas advindos do poder público, o que seria explorado por legisladores na formação de clientelas locais. Se tal hipótese se sustenta, pode-se esperar que, em estados com maior proporção de pobres, a reeleição dos legisladores seja maior.

$\mathrm{Na}$ análise que segue, utiliza-se uma regressão logística binária para testar o modelo que toma como variável dependente o sucesso eleitoral dos candidatos à reeleição para a Câmara dos Deputados em 2006. Essa variável é definida como reeleito (1) ou não (0) para a legislatura 2007-2010.

0 modelo proposto pode ser resumido conceitualmente conforme apresentado abaixo:

\footnotetext{
${ }^{23}$ Utilizou-se a classificação dos partidos na escala de direita x esquerda resultante da pesquisa "Trajetórias, perfis e padrões de interação de legisladores estaduais em doze unidades da federação", realizada em 2007 e 2008, pelo Centro de Estudos Legislativos do Departamento de Ciência Política da Universidade Federal de Minas Gerais. Ver Castro, Anastásia e Nunes (2009).

24 O cálculo da variável pork foi feito utilizando-se os dados de execução orçamentária disponibilizados pela Secretaria do Tesouro Nacional (STN). Através desse banco de dados, é possível identificar a autoria de grande parte das emendas individuais de parlamentares, executadas pelo governo. Essa informação permite identificar qual o montante de recurso que cada parlamentar conseguiu ver executado por ano. Para esse artigo, utilizou-se a taxa de sucesso de execução de emendas para o ano de 2005, período anterior as eleições, mas próximo o suficiente para produzir o controle esperado.

25 Fonte: IPEA, 2006. Pobre é considerado aquele que recebe menos de 3/4 de salário mínimo por mês.
} 


$$
\begin{gathered}
\operatorname{Re}_{\text {eleito }_{i}} \sim \operatorname{Bernoulli}\left(\pi_{i}\right) \\
\pi_{i}=\Lambda\left(X_{i} \beta\right)
\end{gathered}
$$

onde, $X_{i}$ é um vetor de variáveis independentes: \{Mensalão, Sanguessugas, sexo, idade, escolaridade, percentual de pobres por distrito eleitoral, partido por sua posição ideológica, número de candidatos por vaga, gastos de campanha, diferença de votos em relação à eleição anterior, migração partidária e emendas orçamentárias para as bases eleitorais\}. Devido à ausência de dados para alguns candidatos, utilizou-se o Amelia II para imputar valores para as variáveis de controle utilizadas, de forma que o modelo especificado possa usar o maior número de informação possível (HONAKER; KING; BLACKWELL, 2011).

Antes de explorar os resultados do modelo logístico apresentado, procurou-se verificar se a taxa de sucesso eleitoral varia por estado, o que implicaria a necessidade de considerá-la como variável contextual na análise. O Gráfico 1 mostra o valor esperado da taxa de reeleição para cada estado brasileiro calculado a partir de um modelo de regressão logística simples. Cada valor estimado é plotado com o valor do intervalo de confiança calculado para cada estado.

Os dados mostram que não há diferença no valor esperado que justifique a inclusão da variável estado no modelo de regressão. Embora haja diferença significativa entre os estados nos dois extremos, Ceará e São Paulo, no que se refere à taxa esperada de reeleição de candidatos, a variação total, comparando cada caso, não indica a necessidade de utilização da variável. A conclusão é de que não há nenhuma associação entre a região do país e a taxa de reeleição dos deputados federais. Note-se que os estados em que os legisladores foram menos reeleitos, São Paulo, Amapá, Rio Grande do Norte, e Bahia, assim como aqueles em que foram mais recompensados com a reeleição, Ceará, Paraíba, Santa Catarina e Espírito Santo, pertencem a regiões geográficas diferentes.

Gráfico 1

Reeleição Média de Deputados Federais por Estado, Brasil (2006)

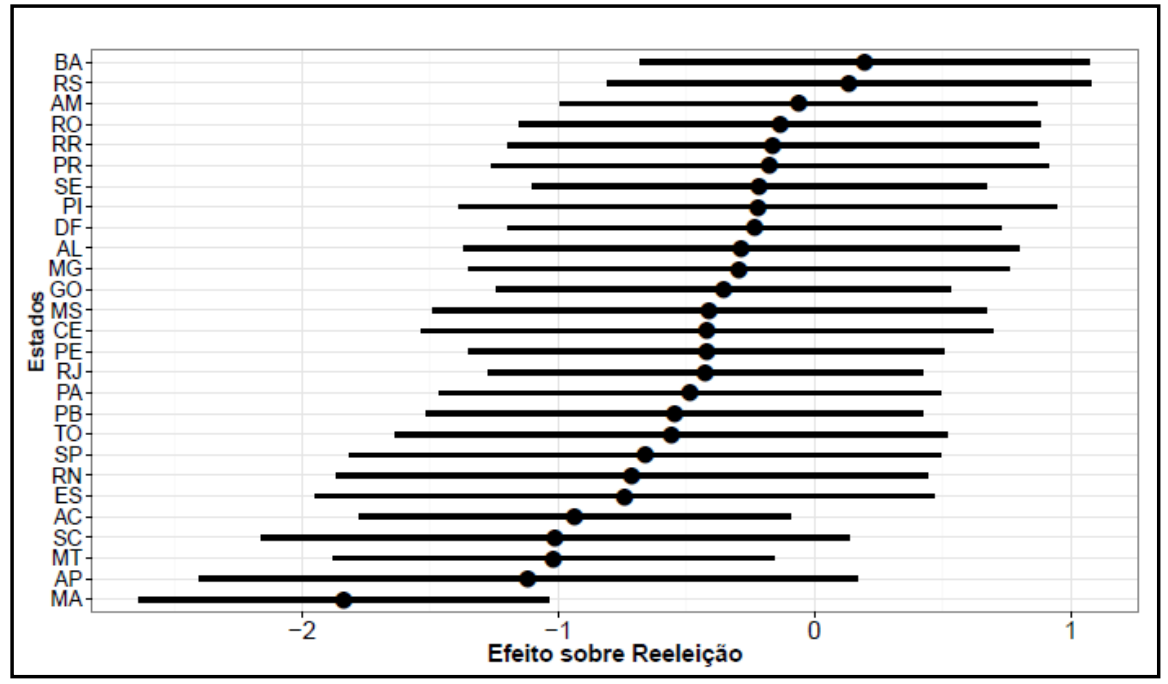


CASTRO, M. M. M.; NUNES, F. Candidatos corruptos são punidos?...

Decidiu-se, então, excluir distrito eleitoral e região geográfica dos modelos explicativos considerados a seguir. Entretanto, como explicitado acima, levando-se em conta a perspectiva sociológica, incluiu-se na análise o fator o grau de pobreza estadual, medido para o ano de 2006, como controle da variância estadual.

\section{Resultados e Discussão}

Tabela 6

Modelo de Regressão Logística Binária

Variável Dependente: Reeleição

\begin{tabular}{|c|c|c|c|c|c|}
\hline Variáveis & Modelo 1 & Modelo 2 & Modelo 3 & Modelo 4 & Modelo 5 \\
\hline \multirow[t]{2}{*}{ (Intercepto) } & $-1.55^{* * *}$ & $-4.53^{* * *}$ & .0 .02 & 0.42 & 0.57 \\
\hline & $(0.06)$ & $(0.21)$ & $(0.38)$ & $(0.93)$ & $(0.95)$ \\
\hline \multirow[t]{2}{*}{ Pobreza } & $0.69 * * *$ & $0.86^{* * *}$ & & 0.67 & 0.77 \\
\hline & $(0.17)$ & $(0.18)$ & & $(0.84)$ & $(0.85)$ \\
\hline \multirow[t]{2}{*}{ Masculino } & & $0.29 * *$ & & .0 .01 & .0 .06 \\
\hline & & $(0.09)$ & & $(0.34)$ & $(0.34)$ \\
\hline \multirow[t]{2}{*}{ Idade } & & $0.03^{* * * *}$ & & .0 .01 & .0 .01 \\
\hline & & $(0.00)$ & & $(0.01)$ & $(0.01)$ \\
\hline \multicolumn{2}{|l|}{ Escolaridade } & $0.25^{* * *}$ & & .0 .04 & .0 .06 \\
\hline & & $(0.03)$ & & $(0.10)$ & $(0.10)$ \\
\hline \multirow[t]{2}{*}{ Ideologia } & & & .0 .16 & .0 .07 & .0 .07 \\
\hline & & & $(0.12)$ & $(0.13)$ & $(0.14)$ \\
\hline \multicolumn{2}{|l|}{ Aumentou Votos } & & $0.73^{* * *}$ & $0.55^{* *}$ & $0.59 * *$ \\
\hline & & & $(0.19)$ & $(0.20)$ & $(0.21)$ \\
\hline \multirow[t]{2}{*}{ Migrante } & & & .0 .05 & 0.02 & 0.08 \\
\hline & & & $(0.22)$ & $(0.23)$ & $(0.23)$ \\
\hline \multicolumn{2}{|c|}{ Emendas Parlamentares } & & .0 .29 & .0 .11 & .0 .17 \\
\hline & & & $(0.36)$ & $(0.38)$ & $(0.38)$ \\
\hline \multicolumn{2}{|l|}{ Candidatos/vaga } & & .0 .01 & .0 .00 & .0 .00 \\
\hline & & & $(0.00)$ & $(0.01)$ & $(0.01)$ \\
\hline \multicolumn{2}{|c|}{ Despesas de Campanha } & & $0.00 * * *$ & $0.00 * * *$ & $0.00 * * *$ \\
\hline & & & $(0.00)$ & $(0.00)$ & $(0.00)$ \\
\hline \multirow[t]{2}{*}{ Escândalo } & & & & $-1.03^{* * *}$ & \\
\hline & & & & $(0.30)$ & \\
\hline \multirow[t]{2}{*}{ Mensalão } & & & & & .0 .54 \\
\hline & & & & & $(0.60)$ \\
\hline \multicolumn{2}{|c|}{ Mensalão e Sanguessugas } & & & & 4.86 \\
\hline & & & & & $(235.0)$ \\
\hline \multicolumn{2}{|l|}{ Sanguessugas } & & & & $-1.34^{* * *}$ \\
\hline & & & & & $(0.39)$ \\
\hline Cox-Snell R-sq. & 0.00 & 0.06 & 0.18 & 0.23 & 0.24 \\
\hline Nagelkerke R.sq. & 0.01 & 0.13 & 0.24 & 0.31 & 0.33 \\
\hline Likelihood-ratio & 15.44 & 312.00 & 42.59 & 55.99 & 60.49 \\
\hline $\mathrm{BIC}$ & 3059.22 & 2788.29 & 288.85 & 302.34 & 308.60 \\
\hline $\mathrm{N}$ & 5148 & 5148 & 217 & 217 & 217 \\
\hline
\end{tabular}

Fonte: TSE. Elaboração própria. (1) A tabela mostra os betas estimados, e os erros padrões - entre parênteses. Para identificar a magnitude do efeito de cada variável independente é preciso calcular o exponencial dos betas estimados, diminuir 1 e multiplicar por $100 \%$. Assim, é possível tratar da probabilidade de que o evento ocorra pelo controle das variáveis do modelo. ${ }^{* * *} P<=0,01$ $* * \mathrm{P}<=0,05$ 
Os resultados da regressão, apresentados na Tabela 6, mostram que as variáveis do perfil do parlamentar, sexo, idade, e escolaridade, têm associações relevantes no modelo explicativo. Observe-se, no Modelo 2 que, além de estatisticamente significativos, os efeitos de tais variáveis são substantivamente altos. Homens têm mais chance de serem reeleitos; aumento de um ano na idade, assim como escolaridade mais alta têm esse mesmo efeito.

Chama atenção, também, a influência do nível de pobreza do distrito eleitoral na probabilidade de reeleição: onde há mais pobreza, as chances de reeleição dos deputados são substantivamente maiores.

No Modelo 3 foram introduzidas as variáveis políticas e institucionais propostas anteriormente. Surgem, então, alguns resultados bastante interessantes. Mantendo a tendência observada em 2002, parlamentares de partidos de esquerda e centro tiveram maiores chances de serem reeleitos, em comparação aos deputados de partidos da direita. Esse resultado sugere que a proximidade com o governo Lula, apesar de centro dos escândalos de corrupção, não reduziu as chances de vitória dos legisladores. Ao contrário, parece reforçada a tese de que a vitória de um partido ou de uma coalizão na eleição majoritária é fator de ampliação da base legislativa ligada a ela. Como proposto na literatura (Cox, 1996; MELo, 2010), a eleição para o Executivo tende a 'contaminar' à do Legislativo quando ambas acontecem concomitantemente.

Como já mostrado para a eleição de 1998, por Pereira e Rennó (2001), o volume de recursos investidos na campanha eleitoral de 2006, conforme a informação dada pelos candidatos, não tem nenhuma influência sobre a probabilidade de um parlamentar conquistar uma cadeira no Legislativo, e esse não efeito é estatisticamente significativo. Isso se observa independentemente dos atributos pessoais, partidários e dos fatores contextuais (Modelo 4). A alocação bem sucedida de recursos particularistas (pork) não apresenta, diferentemente do que era esperado, associação positiva com reeleição. O resultado parece ser nulo e não relevante para explicar as chances de reeleição, em 2006, também quando variáveis socioeconômicas e institucionais são incluídas no modelo.

Finalmente, também é possível observar, no Modelo 4, que o aumento do número de votos nominais recebidos pelos candidatos tem impacto positivo e substantivamente relevante nas suas chances de reeleição. Esses resultados reafirmam o que foi apresentado na segunda seção deste artigo, para as eleições de 2006.

Se a tese de Melo (2000), de que deputados migram de partido na expectativa de aumentar suas chances eleitorais no próximo pleito, se sustenta, os resultados aqui analisados evidenciam, no mínimo, que aquela decisão não obteve os resultados desejados e esperados: não há diferença na probabilidade de um parlamentar que migrou de partido pelo menos uma vez durante a legislatura 2003. 2006 se reeleger, em comparação com deputados que se mantiveram na mesma agremiação.

Os resultados até aqui analisados fortalecem alguns dos achados mais importantes sobre reeleição legislativa no Brasil, também para a eleição de 2006. Mas os dois últimos Modelos (5 e 6) são os que respondem ao problema central proposto neste artigo: como o envolvimento dos legisladores nos escândalos influenciou suas chances de obterem sucesso eleitoral.

O efeito da principal variável independente, a denúncia de participação nos escândalos de corrupção no governo Lula, é instigante. Os resultados mostram que o envolvimento em algum dos dois 
CASTRO, M. M. M.; NUNES, F. Candidatos corruptos são punidos?...

escândalos reduz drasticamente as chances de o legislador conquistar uma nova vaga na Câmara, mesmo controlando-se todas as variáveis previamente consideradas (-64\%). Mas, o mais interessante é que esse efeito não é o mesmo para os dois escândalos. Conforme o Modelo 6 mostra, o envolvimento no Mensalão diminui em $42 \%$ a chance de reeleição dos deputados, se comparados com os não envolvidos nas denúncias. Contudo, esse resultado não pode ser distinguido estatisticamente de um resultado em que o efeito é nulo.

Também conforme esperado, legisladores envolvidos com os Sanguessugas tiveram diminuídas em $73 \%$ as chances de manterem sua cadeira no Legislativo, se comparados com os que não estiveram envolvidos. Esse resultado, além de estatisticamente significativo é substantivamente relevante. Mesmo controlando por todas as variáveis supracitadas, a participação nos Sanguessugas foi dolosa para os legisladores.

Os Gráficos 2 e 3 ajudam a visualizar melhor os resultados da regressão logística. Conforme mostra o Gráfico 2, a punição aos legisladores é mais severa se seus nomes estão envolvidos no escândalo dos Sanguessugas. A punição para o Mensalão pode ser considerada nula, embora alguns deputados da direita tenham se beneficiado com a reeleição mesmo tendo tido envolvimento nesse escândalo. Importa chamar a atenção para o fato de que, proporcionalmente, a direita foi mais punida do que a esquerda no caso dos Sanguessugas. Mas o contrário é verdadeiro no caso do Mensalão.

Gráfico 2

Proporção de Reeleição por Ideologia e Escândalo

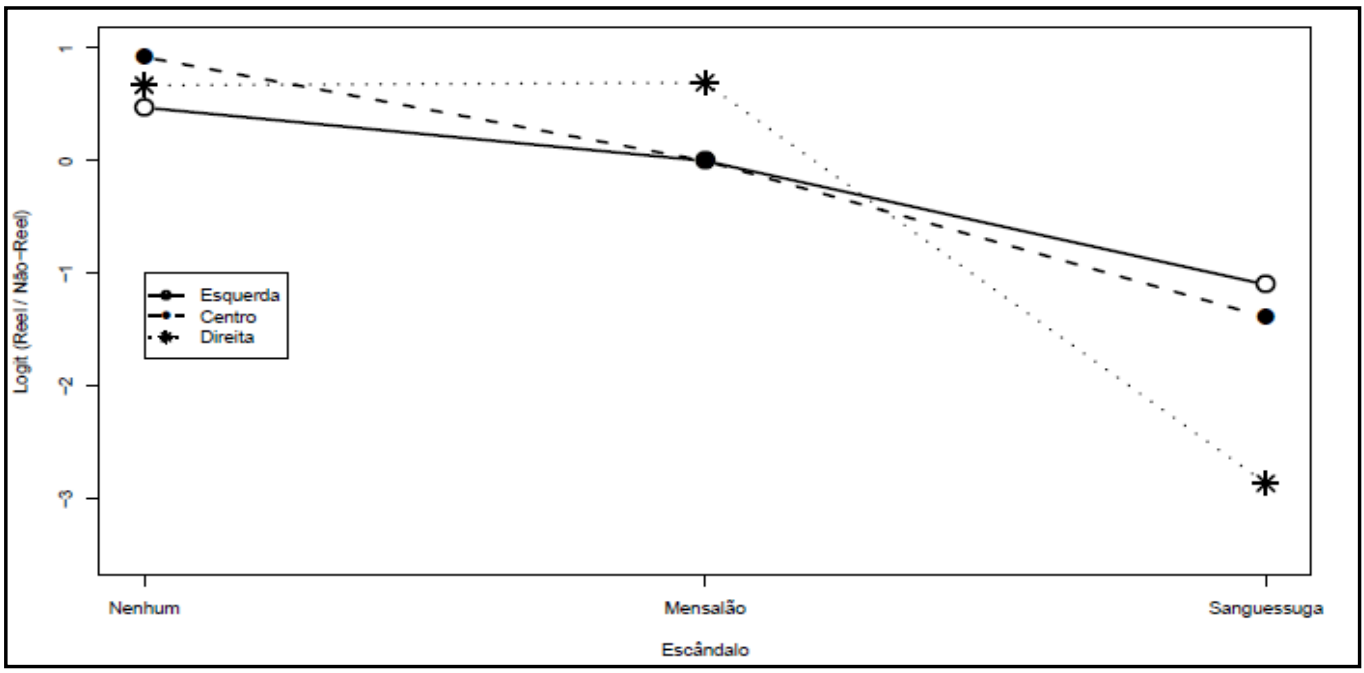

O Gráfico 3 traz uma comparação ainda mais interessante. Agora, não só a participação nos escândalos é contrastada com ideologia, mas também com duas outras importantes variáveis do modelo: aumento de votos de uma eleição para a outra, e o nível de pobreza estadual. A comparação dos quatro gráficos permite concluir que: (1) em todos os cenários analisados, a participação nos Sanguessugas é mais dolosa do que a participação no Mensalão; (2) legisladores provenientes de estados mais pobres tendem a ser menos punidos eleitoralmente, mas especialmente se eles são 
membros de partidos de esquerda e mantiveram a mesma votação na eleição anterior; (3) aumento na votação entre eleições está associado a baixos índices de punição em todos os cenários; e, finalmente, (4) esquerda e direita parecem não sofrer distintas avaliações quando os controles aqui utilizados são incluídos na análise:

Gráfico 3

Probabilidade de Reeleição Estimada por Pobreza, Ideologia, Tipo de Escândalo e Votos Recebidos - Brasil (2006)

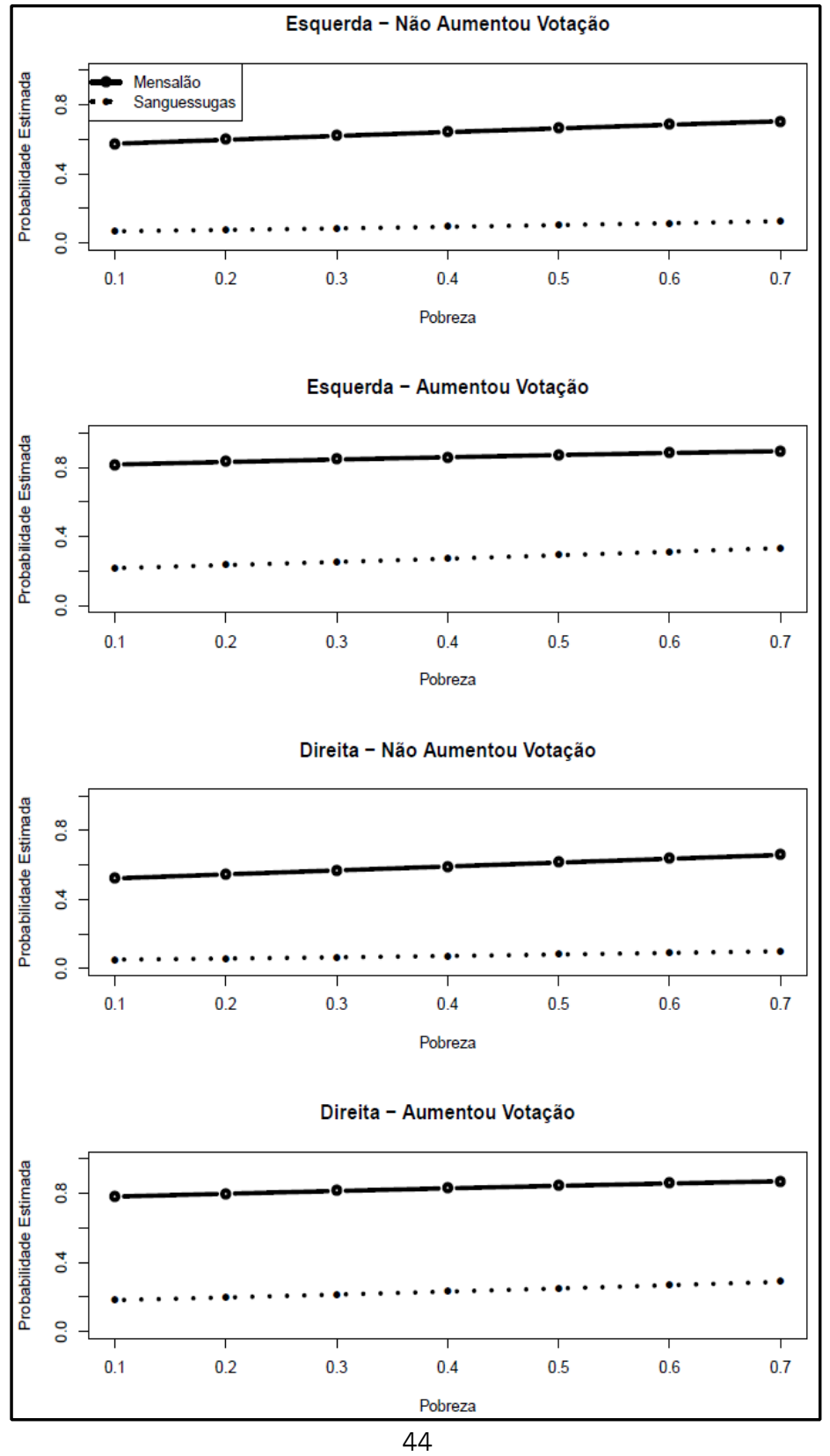


CASTRO, M. M. M.; NUNES, F. Candidatos corruptos são punidos?...

Tais resultados levam a crer ser possível sustentar as conclusões sugeridas no fim da terceira seção deste artigo: a proximidade das denúncias em relação ao processo eleitoral é fator relevante para explicar as chances de reeleição. E, por outro lado, considerando a literatura que trata das condições de reeleição no Brasil, os resultados reforçam, também, a importância do fator proposto por Pereira e Rennó (2007): a proximidade com o presidente que está, também, concorrendo à reeleição. Como se viu, foram principalmente deputados do partido do presidente, envolvidos no Mensalão, que, comparativamente, foram menos punidos pelos eleitores, em 2006. Por outro lado, o escândalo dos Sanguessugas foi denunciado pelo próprio governo e afetou, principalmente, deputados de sua base parlamentar mais à direita, e deputados de partidos da oposição.

Em síntese, parece ser possível sustentar a hipótese de que o eleitorado brasileiro foi capaz de punir os legisladores envolvidos nos escândalos de corrupção, embora tal mecanismo tenha funcionado especialmente quando a memória do eleitor ainda relaciona o candidato à denúncia. Esses resultados, portanto, parecem indicar que um sistema democrático mais eficaz, ou seja, mais accountable é aquele capaz de produzir mecanismos facilitadores de difusão e manutenção da informação para os eleitores. Se a participação nos escândalos foi vista negativamente e ajudou os eleitores a identificar os legisladores que mereciam punição, tal processo só aconteceu porque a distância entre o momento de punição e o recebimento da informação foi curto o suficiente.

Ressalta-se, por fim, que estes resultados acompanham o que previsto nos modelos formais de agência elaborados por Besley (2007) para sistemas democráticos modernos. Nas conclusões, o autor afirma que a produção de resultados benéficos à população se dá quando legisladores têm poucos incentivos para buscar benefícios privados. Besley sustenta que a manutenção de tais incentivos, no entanto, depende da diminuição da assimetria informacional que separa eleitores de políticos. O que este artigo mostra, por sua vez, é que os resultados positivos em sistemas democráticos podem depender do fim dessas assimetrias, mas que este último fator pode ser influenciado pela distância temporal entre a implementação de resultados e as eleições.

\section{Considerações Finais}

Os dados analisados neste artigo mostram que o exercício do processo de accountability vertical, no Brasil, depende de uma série de fatores. Para explicar as possibilidades de punição ou de recompensa dos políticos, por meio do voto, é preciso levar em conta variáveis que se referem não só às condições institucionais e político-partidárias e ao comportamento dos políticos, mas também, à situação socioeconômica do contexto em que os políticos atuam e à distância de tempo entre a observação de resultados e as eleições. O país ainda tem alto grau de desigualdade social, que varia nos municípios, estados e regiões; essa condição, certamente, implica dificuldades maiores ou menores para os eleitores obterem informação necessária ao exercício autônomo do direito de voto.

Mostrou-se que os eleitores foram capazes de punir os legisladores envolvidos em escândalos políticos (corrupção), especialmente enquanto há condição de se lembrarem de tal associação. Os dados indicam que a variável tempo ganha relevância quando se pretende explicar em que contextos ou condições políticos são punidos, mesmo em sistemas que favorecem o voto prospectivo.

Nas condições brasileiras, a eleição dos membros do Poder Legislativo federal parece se caracterizar, ainda, em grande parte, pelo voto prospectivo, baseado nas expectativas que os eleitores 
colocam em políticos novatos, do que pelo voto retrospectivo, que reflete a fiscalização e avaliação do trabalho realizado pelos deputados, no exercício do mandato.

Entretanto, os dados mostram, também, algum avanço do país em direção da responsabilização dos políticos por sua atuação na Câmara dos Deputados. As denúncias de corrupção, especialmente aquelas feitas no ano da eleição, tiveram consequências claras: aumentaram, em muito, as chances de punição dos envolvidos, por parte do eleitorado.

Como bem comenta Reis,

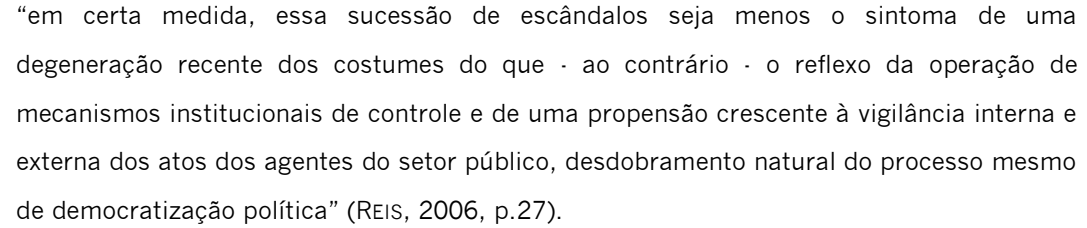

Finalmente, é preciso enfatizar que os resultados da análise aqui realizada permitem reforçar a expectativa de que os avanços recentes nas condições de vida no Brasil, especialmente a queda no grau de desigualdade social, evidenciada nos dados dos últimos anos, tenham efeitos positivos e duradouros na vida política do país.

\section{Referências Bibliográficas}

AmEs, B. The deadlock of democracy in Brazil. Ann Arbor: University of Michigan Press, 2001.

ANDRADE, L. A. G. O município na política brasileira: revisitando coronelismo, enxada e voto. In: CINTRA, A. O.; AvELAR, L. (orgs.) Sistema político brasileiro: uma introdução. $2^{a}$. ed. Rio de Janeiro: Fundação Konrad-Adenauer-Stiftung; São Paulo: Ed. UNESP, 2007.

BAQUERO, M. Novos padrões de comportamento eleitoral nas eleições municipais de 1996. In: BAQUERO. M. (org.). $A$ lógica do processo eleitoral em tempos modernos: novas perspectivas de análise. Porto Alegre: Ed. UFRGS/La Salle, 1997.

BesLey, T. Principled agents? Cambridge: Cambridge University Press, 2007.

CAmpBeLl, J. E. "The presidential pulse and the 1994 midterm congressional election". The Journal of Politics, vol. 59, n'3, p. $830 \cdot 857,1997$.

CAREY, J.; SHUGART, M. S. "Incentives to cultivate a personal vote: a rank ordering of electoral formulas". Electoral Studies, vol. 14, n 4, p. 417.439, 1995.

CAstro, M.M.M. “Regras eleitorais”. Estado de Minas, Belo Horizonte, p.11, 5 dez. 2007.

ANASTASIA, F.; NUNES, F. "Determinantes do comportamento particularista de legisladores estaduais". Dados, Rio de Janeiro, vol. 52, n 4, p. 961-1001, 2009

Cireno, F.; LubAmBo, C. Estratégia eleitoral e eleições para Câmara dos Deputados no Brasil em 2006, no prelo.

Cox, G. Making votes count: strategic coordination in the world's electoral systems. Cambridge: University Press, 1997.

MAGAR, E. "How much is majority status in the US Congress worth?" American Political Science Review, vol. 93,

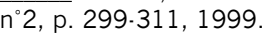

McCubBins, M. Setting the agenda. Cambridge: Cambridge University Press, 2005. 
CASTRO, M. M. M.; NUNES, F. Candidatos corruptos são punidos?...

DAHL, R. Um prefácio à teoria democrática. Rio de Janeiro: Jorge Zahar Ed., 1989.

ERIKSON, R. S. "The puzzle of midterm loss". The Journal of Politics, vol. 50, n 4, p. 1011-1029, 1988.

FigueIREDo, A.; LIMONGI, F. Executivo e legislativo na nova ordem constitucional. Rio de Janeiro: FGV, 1999.

HonAKER, J.; KING, G.; BlACKWELL, M. “Amelia II: a program for missing data." Journal of Statistical Software, vol.45, $n^{\circ} 7$, 2011.

JACOBSON, G. "The effects of campaign spending in House elections: new evidence for old arguments". American Journal of Political Science, vol. 31, n 1, p. 126. 141, 1990.

KAZEe, T.; THORnBerRy, M. "Where is the party? Congressional candidate recruitment and American party organizations". Western Political Quarterly, vol. 43, n’ 1, p. 61.80, 1990.

Krasno, J. S.; Green, D. P.; Cowden, J. A. "The dynamics of campaign fundraising in House elections". The Journal of Politics, vol. 56, n² 2, p. 459.474, 1994.

LAmounier, B. Partidos e utopias: o Brasil no limiar dos anos 80. São Paulo: Loyola, 1989.

LEAL, V. N. Coronelismo, enxada e voto. São Paulo: Cultrix, 1975.

LEEX. Almanaque dos dados eleitorais: Brasil e outros países. Disponível em: <http://www3.ucam.edu.br/leex/index.asp>. Acesso em: 20 nov.2011.

Leoni, E.; PereiRa, C.; Rennó, L. "Political survival strategies: political career decisions in the Brazilian Chamber of Deputies." Journal of Latin American Studies, vol.36, n¹, 2004.

LIJPHART, A. Pattern's of democracy. government forms and performance in thirty-six countries. New Haven: Yale University Press, 1999.

MAYHEW, D. Congress: the electoral connection. New Haven: Yale University Press, 1974.

Melo, C. R. F. "Partidos e migração partidária na Câmara dos Deputados". Dados, vol. 43, n’ 2, 2000.

Retirando as cadeiras do lugar. Belo Horizonte: UFMG, 2004.

"As instituições brasileiras funcionam?" Revista de Sociologia e Política, Curitiba, vol. 25, 2005.

"Eleições presidenciais, jogos aninhados e sistema partidário no Brasil." Revista Brasileira de Ciência Política, vol.13, n41, 2010.

NicolAU, J. Multipartidarismo e democracia: um estudo sobre o sistema partidário brasileiro, 1985.94. Rio de Janeiro: Ed. FGV, 1996.

"Como controlar o representante? Considerações sobre as eleições para a Câmara dos Deputados no Brasil." Dados, vol. 45, n², p. 219.236, 2002.

O'DONELL, G. "Horizontal accountability and new polyarchies". Conferência: Institutionalizing Horizontal Accountability." Vienna: Institute for advanced studies of Vienna and the international forum for democratic studies, jun. 1997.

"Further thoughts on Horizontal Accountability". Seminário: Institutions, Accountability and Democratic Governance in Latin American." Notre Dame: Kellogg Institute for International Studies/University of Notre Dame. Notre Dame, May.2000.

PereiRA, C.; RENNó, L. "O que é que o reeleito tem? Dinâmicas político-institucionais locais e nacionais nas eleições de 1998 para a Câmara dos Deputados." Dados, vol. 44, n², 2001.

"O que é que o reeleito tem? O retorno: o esboço de uma teoria da reeleição no Brasil." Revista de Economia e Política, vol. 27, n 4, p. 664-683, 2007.

; SAmUels, D. Corruption, campaign finance, and reelection. In: Corruption and democracy in Brazil: The struggle for accountability. Notre Dame: University of Notre Dame Press, 2011.

PereIRA, C. "What are the conditions for the presidential success in the legislative arena? The Brazilian electoral connection." Ph.D. Thesis, The New School University, New York, 2000. 
Powell Jr., B. Elections as instrument of democracy. New Haven: Yale University Press, 2000.

Przeworski, A.; Stokes, S. C.; Manin, B. (eds.). Democracy, accountability and representation. New York: Cambridge University Press, 1999

REIS, B. W. "O Presidencialismo de Coalizão sob Pressão: da formação de maiorias democráticas à formação democrática de maiorias." Revista Plenarium, n4, p.80-103, 2007.

RENNO, L. "Microfoundations of social capital: civic engagement in Latin America". Encontro Annual, Midwest Political Science Association, Chicago, 2000.

2007.

“Escândalos e voto: as eleições presidenciais brasileiras de 2006." Opinião Pública, Campinas, vol. 13, n²,

SAEZ, M. A.; LoPEZ, F. S. "Las relaciones ejecutivo-legislativo en América Latina: un análisis de la estructura de veto insistencia y control político." Revista de Estudios Politicos, n² 112, abr-jun. 2001.

SAmUELS, D. "The gubernatorial coattails effect: federalism and congressional elections in Brazil." The Journal of Politics, vol. $62(1)$, p. $240 \cdot 253,2000$.

"Pork-barreling is not credit-claiming or advertising: campaign finance and the sources of the personal vote in Brazil." The Journal of Politics, vol. 64, n³, p. 845-863, 2002.

SANTOS, F. "Recruitment and retention of legislators in Brazil." Legislative Studies Quarterly, vol. 24, n², p. 209.237, 1999.

Deputados federais e instituições legislativas no Brasil: 1946-99. In: BoschI, R.; DInIZ, E.; SANTOS, F. Elites políticas e econômicas no Brasil contemporâneo. São Paulo: Fundação Konrad-Adenauer, Série Pesquisas, n¹8, 2000.

SCHWINDT-BAYER, L. "Making quotas work: the effect of gender quota laws on the election of women." Legislative Studies Quarterly, vol. 5, n’28, 2009.

Strom, K. Parties at the core of government. In: Dalton, R.; WATtemberg, M. (eds.). Parties without partisans. Oxford: Oxford University Press, 2000.

TAVARES, J. A. G. Reforma política e retrocesso democrático: agenda para reformas pontuais no sistema eleitoral e partidário brasileiro. Porto Alegre: Ed. Mercado Aberto, 1998.

Zucco, C. "The President's 'New' Constituency: Lula and the Programatic Vote in Brazil's 2006 Presidential Elections." Journal of Latin American Studies, vol. 40, n²1, 2008.

Mônica Mata Machado de Castro - monicammc@terra.com.br

Felipe Nunes ·felipenunes@ucla.edu

Submetido à publicação em setembro de 2012.

Versão final aprovada em abril de 2013. 